\title{
Impact of limited short-term sea scallop fishery on epibenthic community of Georges Bank closed areas
}

\author{
Kevin D. E. Stokesbury*, Bradley P. Harris \\ School for Marine Science and Technology, University of Massachusetts Dartmouth, 706 South Rodney French Boulevard, \\ New Bedford, Massachusetts 02744-1221, USA
}

\begin{abstract}
On Georges Bank, 2 areas that had been closed to sea scallop fishing since 1994 were opened for a limited harvest from August 2000 to February 2001. The effects of this limited short-term fishery on the epibenthic community were examined using a 'before/after, control/impact' environmental design conducted with video surveys. A centric systematic survey with 1379 stations placed on a $1.57 \mathrm{~km}$ grid, with 4 video quadrats collected at each station $\left(3.235 \mathrm{~m}^{2}\right.$ per quadrat equaling $17789 \mathrm{~m}^{2}$ total sample area), was completed in 2 control and 2 impact areas before and after the fishery. The sea scallops Placopecten magellanicus and starfishes (primarily Asterias vulgaris) comprised more than $84 \%$ of the fauna. Changes in the number of taxonomic categories and the density of individuals within each category in the areas impacted by the fishery were similar to changes in the control areas that remained closed to fishing. Further, sediment composition shifted between surveys more than epibenthic faunal composition, suggesting that this community is adapted to a dynamic environment. The limited short-term sea scallop fishery on Georges Bank appeared to alter the epibenthic community less than the natural dynamic environmental conditions.
\end{abstract}

KEY WORDS: Sea scallop · Video · Georges Bank · Fishing impact · Before/after, control/impact $\mathrm{BACI} \cdot$ Closed areas

Resale or republication not permitted without written consent of the publisher

\section{INTRODUCTION}

The sea scallops Placopecten magellanicus support the second largest fishery in the NE United States and are managed as 2 stocks, Georges Bank and the Mid-Atlantic (Murawski et al. 2000, Stokesbury et al. 2004). To harvest sea scallops in these areas, fishing vessels $(25$ to $30 \mathrm{~m}$ long) usually deploy 2 New Bedford offshore dredges (Bourne 1964, Caddy 1989) (present study Fig. 1).

Scallop dredging may impact the benthic community by reducing densities and shifting spatial distribution of macrofaunal populations (Langton et al. 1987, Langton \& Robinson 1990, Thrush et al. 1995, Kenchington 2000, Bradshaw et al. 2002), by removing colonial epifauna and reducing habitat complexity (Dayton et al. 1995, Auster et al. 1996, Collie et al. 1997, Collie \& Escanero 2000, Hall-Spencer \& Moore 2000), and by redistributing grain size of sediments and increasing silt in the water column (Caddy 1989, Mayer et al. 1991, Grant 2000, MacDonald 2000). Unfortunately, many studies do not assess disturbances caused by scallop dredging against a background of natural disturbance that occurs over time (Kaiser et al. 1996, Jennings \& Kaiser 1998, Watling \& Norse 1998, Auster \& Langton 1999). This is difficult and expensive to do, and as a consequence dredge-impact studies are often hampered by the lack of proper environmental-impact assessment and appropriate monitoring (Thrush et al. 1995, Jennings \& Kaiser 1998).

Because of proposed disturbances caused by scallop dredging and fish trawling, 3 areas on Georges Bank containing approximately $7000 \mathrm{~km}^{2}$ of sea scallop grounds that had been fished since the 1800s were closed to mobile fishing gear in 1994 (Murawski et al. 2000) (see present Fig. 2). By 1999, densities of sea scallops within these areas had increased to the highest ever recorded, and continue to increase (Stokesbury 2002, Stokesbury et al. 2004). As a result, portions of these areas were opened for a single limited sea scallop fishery from 1999 to 2001. 


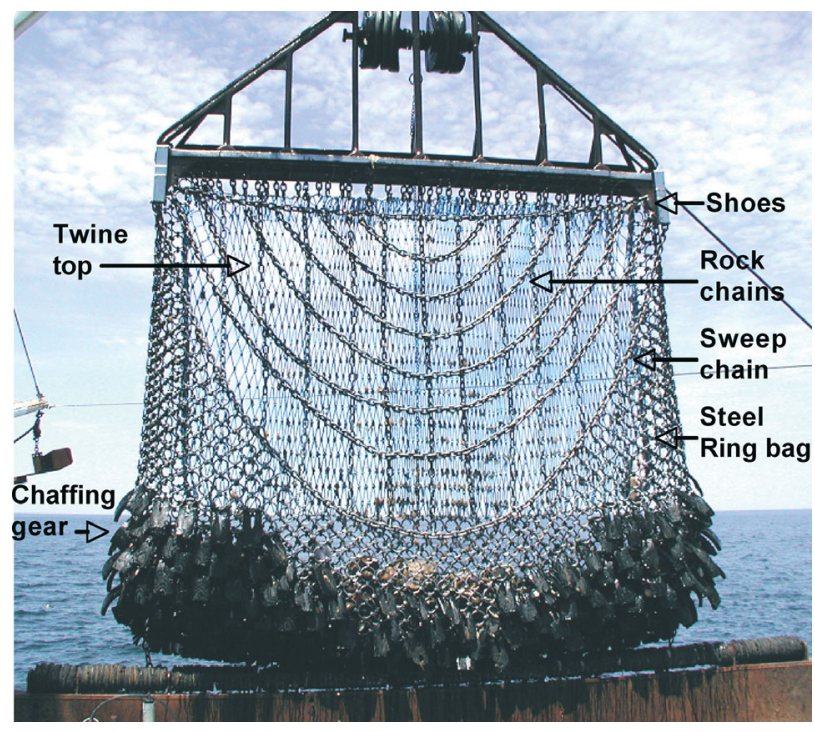

Fig. 1. New Bedford offshore sea scallop dredge used in this fishery, with weight of about $1870 \mathrm{~kg}$, and width of $4.5 \mathrm{~m}$. Dredge comprises series of vertical and horizontal sweep chains (that prevent large rocks from entering the bag) a $20.3 \mathrm{~mm}$ diamond mesh twine top, a $4.5 \times 0.8 \mathrm{~m}$ bag knit of $89 \mathrm{~mm}$ steel rings and rubber chaffing gear

We examined the impact of the limited short-term sea scallop fishery on the epibenthic community of Georges Bank closed areas by conducting a largescale before/after, control/impact (BACI) study (Green 1979, Stewart-Oaten et al. 1986, Krebs 1989, Underwood 1994). The epibenthic community is the group of organisms belonging to a number of different species that co-occur in a habitat and interact spatially and possibly trophically (Putman 1994). The null hypothesis was that changes in the number of taxonomic categories and the density of individuals within each category in the areas impacted by the fishery were similar to changes in the control areas that remained closed to fishing. We examined shifts in the epibenthic community by determining similarity indices, taxonomic category diversity, and the number of individuals within each category, within each area.

\section{MATERIALS AND METHODS}

The BACI study consisted of 2 experiments, each containing an impact area exposed to fishing and an undisturbed control area (Table 1, Fig. 2). The BACI design assumes that the control and impact areas have similar epibenthic communities and environmental conditions, and that these communities will change over time in the same fashion, except for any disturbances caused by scallop dredging in the impact areas.

In Expt I, the northern portion of Closed Area II (CAII) was used as the control area and the Nantucket Lightship Closed Area (NLCA) as the impact area (Fig. 2). The northern portion of CAII is the only location on Georges Bank that has been closed to all mobile fishing since 1994, and has similar scallop densities, substrate and current structure to the NLCA. The mean water depths were $52 \mathrm{~m}(\mathrm{SD}=9.5)$ and $66 \mathrm{~m}(\mathrm{SD}=9.1)$ in the control and impact areas, respectively. Both areas had mid-water tidal currents with maximum averages of about $60 \mathrm{~cm} \mathrm{~s}^{-1}$ (Brown \& Moody 1987). Sand and granule/pebbles made up 74 and $89 \%$ of the sediment

Table 1. Video surveys completed before and after the limited sea scallop fishery in 2 experiments, each with a control and impact area, on Georges Bank. CAII: Closed Area II (northern portion); NLCA: Nantucket Lightship Closed Area; CAIS: Closed Area I South; CAIN: Closed Area I North; (n): number of stations sampled in each survey

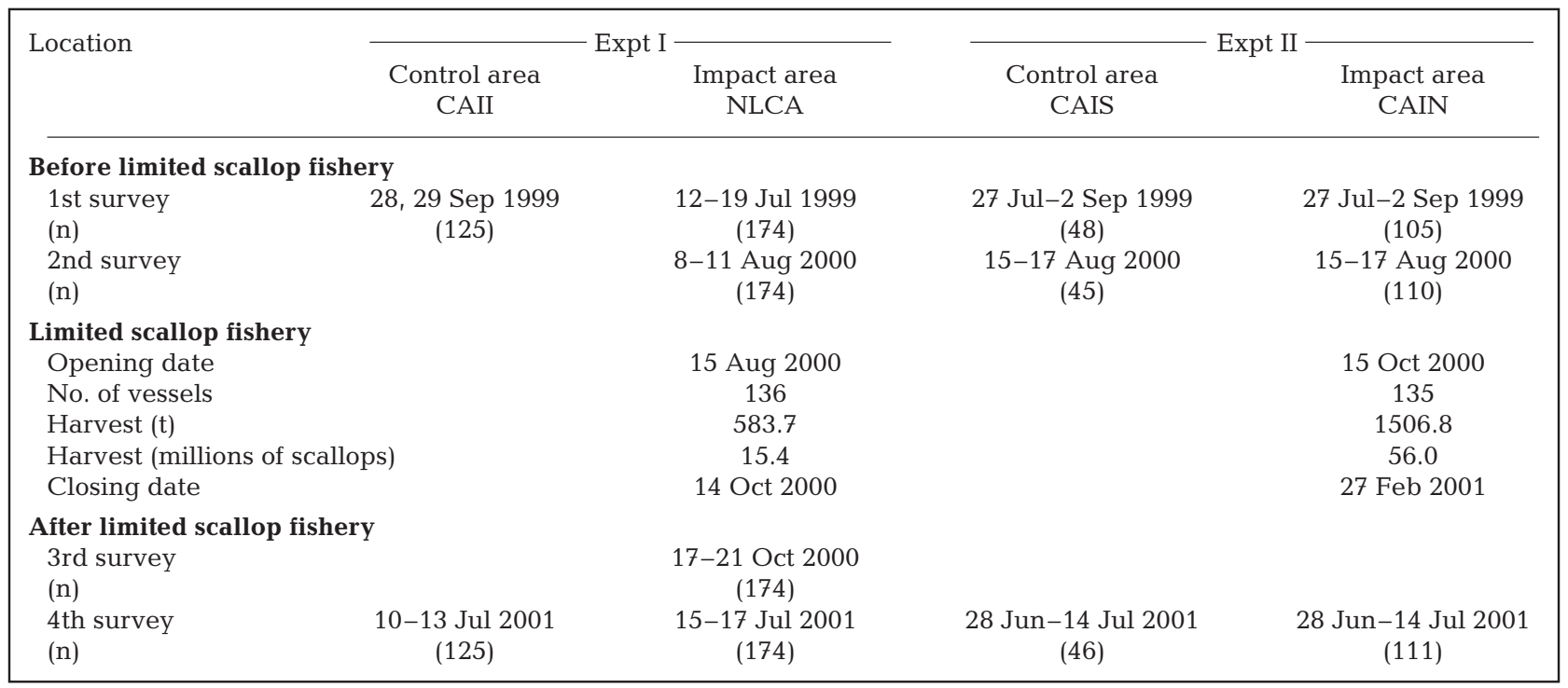


Fig. 2. Georges Bank, showing 1994 groundfish closed areas (NLCA: Nantucket Lightship Closed Area; CAIN, CAIS: Closed Area I, (north and south), respectively; CAII: Closed Area II), the sea scallop exemption fishery access areas (hatched) open for harvesting in 1999 to 2001, and the sea scallop video stations sampled for the before/after, control/impact (BACI) experiment (dots in A and B). $(A, B)$ Enlargements of NLCA and CAIN, detailing fishing effort in impact areas. Shading represents fishing effort, whereby $3-17$ and $17-130 \mathrm{~h} \mathrm{~km}^{-2}=0.2$ to 1.3 and 1.3 to 9.6 dredge passes over entire area, respectively (P. Rago unpubl. data, National Marine Fisheries Service, Woods Hole, MA)

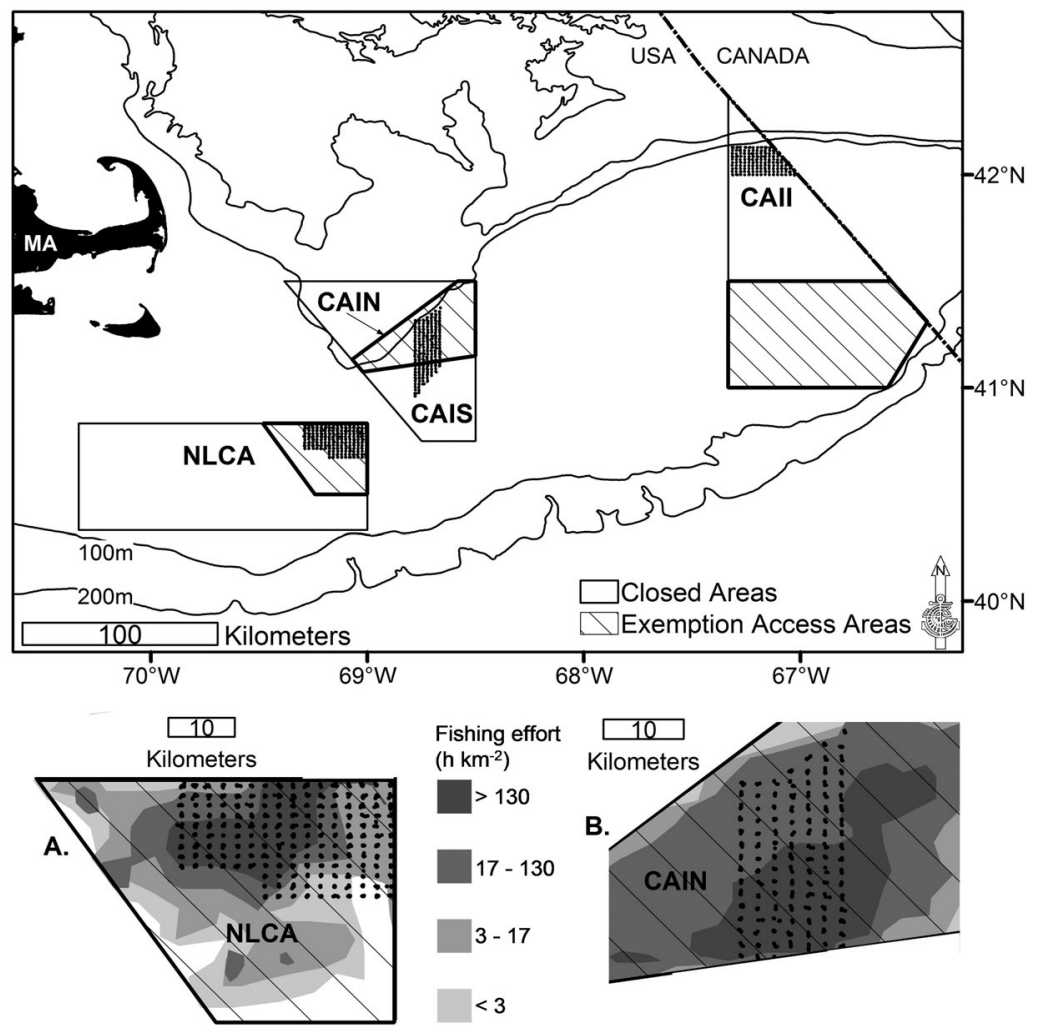

composition in the control and impact areas, respectively. The scallop aggregations covered 235 and $282 \mathrm{~km}^{2}$ of sea floor, with mean densities of 0.78 (SE = $0.092)$ and $0.64(\mathrm{SE}=0.095)$ sea scallop $\mathrm{m}^{-2}$, representing 183 and 180 million scallops (>60 mm shell height) in the control and impact areas, respectively (Stokesbury 2002). Although these areas are separated by about $200 \mathrm{~km}$, they may be linked by transport of larval fishes and invertebrates due to the circulation patterns of Georges Bank (Tremblay et al. 1994).

Expt II was conducted in the central portion of Closed Area I (CAI), which was divided into the southern control area (CAIS) and the northern impact area (CAIN) (Fig. 2). The mean water depths were $61 \mathrm{~m}$ $(\mathrm{SD}=4.2)$ and $70 \mathrm{~m}(\mathrm{SD}=9.7)$ in the control and impact areas, respectively. Both areas had mid-water tidal currents with maximum averages of about $45 \mathrm{~cm} \mathrm{~s}^{-1}$ (Brown \& Moody 1987). Sand and granule/pebbles made up 86 and $99 \%$ of the sediment composition in the control and impact areas, respectively. The scallop aggregations covered 67 and $163 \mathrm{~km}^{2}$ of sea floor with mean densities of $0.60(\mathrm{SE}=0.181)$ and $0.30(\mathrm{SE}=$ 0.061) sea scallops $\mathrm{m}^{-2}$, representing 70 and 69 million scallops (>60 mm shell height) in the control and impact areas, respectively (Stokesbury 2002).

Each area was surveyed at least once before and after the limited short-term sea scallop fishery (Table 1). All areas were surveyed in the summer of
1999. During the summer of 2000, just prior to the scallop harvest, the impact area of Expt I (NLCA) and both areas of Expt II were video surveyed. The impact area of Expt I (NLCA) was also video surveyed again $2 \mathrm{~d}$ after the fishery ended and the control and impact areas were surveyed a final time in July 2001. The control and impact areas of Expt II were video surveyed 4 mo after the fishery ended in June 2001.

A video survey pyramid deployed in a centric systematic sampling design with stations positioned on a $1.57 \mathrm{~km}$ grid, with 4 quadrats sampled at each station, was used to survey all areas. The precision of this survey design ranged from 5 to $15 \%$ for the normal and negative binomial distributions, respectively, based on the density of sea scallops in the Nantucket Lightship area in 1999 (Stokesbury 2002).

The sampling pyramid was deployed from scallop fishing vessels (Stokesbury 2002, Stokesbury et al. 2004) (Fig. 3). A camera was mounted vertically on the pyramid so that once the pyramid rested on the sea floor the camera height was $1575 \mathrm{~mm}$, providing a $2.841 \mathrm{~m}^{2}$ quadrat. All fishes and macroinverebrates were counted, including those only partially visible along the edge of the quadrat image. To correct for this edge effect, $56 \mathrm{~mm}$ (based on half the average shell height of the scallops observed) were added to each edge of the quadrat image, providing a quadrat size of $3.235 \mathrm{~m}^{2}$ (Stokesbury 2002, Stokesbury et al. 2004). 


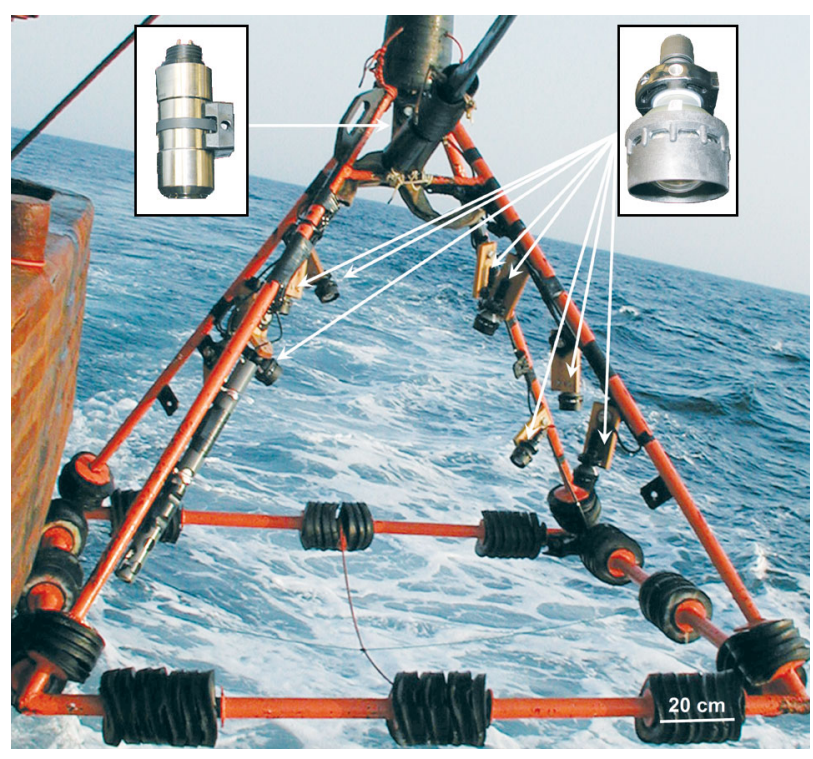

Fig. 3. School for Marine Science and Technology (SMAST) video sampling pyramid aboard the FV 'Huntress'. Pyramid has square base, $2.2 \mathrm{~m}$ per side, of $6 \mathrm{~cm}$ round iron, arms of $2.5 \mathrm{~m} \times 4.5 \mathrm{~cm}$ round iron, and weighs approximately $450 \mathrm{~kg}$. It is deployed with the large hydraulic winch used in the scallop fishing industry while a second tension sensitive hydraulic winch controls the electronic cable. Rubber rings (3 sets of 8 rings, each $20 \mathrm{~cm}$ diameter, $5 \mathrm{~cm}$ thickness, per side) are placed on the base of pyramid to prevent damage during deployment and provide gentle landing on the sea floor. Underwater camera (insert top left, Deepsea Power \& Light ${ }^{\circledR}$ multiSeacam) and up to nine $100 \mathrm{~W}$ lights (insert top right, Deepsea

Power \& Light ${ }^{\circledR}$ multi-Sealite) were attached to pyramid

Collecting 4 quadrats at each station increased the sample area to $12.94 \mathrm{~m}^{2}$.

Fish may be attracted or repelled by light, and this may have affected the numbers we observed. However, as the sample pyramid approached the sea floor, the area illuminated by our lights expanded in all directions and this appeared to confuse many fishes. Most remained still, particularly those using concealment as a means of escaping predators, for example flounder and skates. Once the pyramid landed, if the fishes were within the quadrat area, they hesitated to swim over the cross bar of the pyramid's base, allowing clear identification (Fig. 4).

A monitor and VHS video recorder for the camera, a monitor for the captain controlling the vessel's hydraulic winches to deploy the pyramid, a laptop computer with Arcpad GIS ${ }^{\circledR}$ software integrated with a differential global positioning system and Wide Area Augmentation System (WAAS) receiver, and a laptop computer for data entry were assembled in the wheelhouse. The survey grid was plotted prior to each cruise in Arcpad GIS ${ }^{\circledR} ; 2$ scientists, the captain, mate and 1 deck-hand were able to survey about 100 stations every $24 \mathrm{~h}$.
Video footage of the sea floor was recorded on VHS tapes. For each quadrat, the time, depth, latitude and longitude were recorded. After each survey the videotapes were reviewed in the laboratory and a still image of each quadrat was digitized and saved using Image Pro Plus ${ }^{\circledR}$ software (TIF file format) (Fig. 4). Within each quadrat, fishes and epifaunal macroinvertebrates were counted a second time for quality control and the substrate was identified (Stokesbury 2002, Stokesbury et al. 2004). When possible, fishes and macroinvertebrates, to a minimum size of about $40 \mathrm{~mm}$, were identified to species, and animals were grouped into categories based on taxonomic order (Table 2). Grouping species into higher taxonomic categories increases the power of the statistical analysis, enhancing the detection of anthroprogenic change (Veale et al. 2000). Unidentified fishes were grouped as 'other fish.' Counts were standardized to individuals $\mathrm{m}^{-2}$. For colonial organisms such as sponges, hydrozoans/bryozoans, and sand dollars, which tend to occur in large aggregations, individual counts were difficult or impossible. Therefore, if at least 1 organism of a category was observed, the quadrat was given a value of 1 for this category; however, this differed for the presence/ absence data, as the quadrat did not comprise the total sample for each station.

Sediments were visually identified using texture, color, relief and structure in the video images, roughly following the Wentworth particle-grade scale, where sand = 0.0625 to $2.0 \mathrm{~mm}$, gravel $=2.0$ to $256.0 \mathrm{~mm}$ and boulders are $>256.0 \mathrm{~mm}$ (Lincoln et al. 1992). Gravel was divided into 2 categories, granule/pebble $=2.0$ to $64.0 \mathrm{~mm}$ and cobble $=64.0$ to $256.0 \mathrm{~mm}$ (Lincoln et al. 1992). Shell debris was also identified, but was included with sand as these substrates were often observed together. Quadrats were categorized by the presence of the largest type of particle. Therefore, a quadrat identified as sand contained only sand, but a quadrat with 80 sand and $20 \%$ granule/pebbles was classified as granule/ pebbles (Stokesbury 2002) (present Fig. 4).

Mean densities and standard errors of fishes and macroinvertebrates were calculated using equations for a 2-stage sampling design (Cochran 1977), whereby the mean of the total sample is

$$
\overline{\bar{x}}=\sum_{i=1}^{n}\left(\frac{\bar{x}_{i}}{n}\right)
$$

where $n=$ primary sample units (stations), $\bar{x}_{i}=$ sample mean per element (quadrat) in primary unit $i$ (stations) and $\overline{\bar{X}}=$ the mean over the 2 stages.

The standard error of this mean is

$$
\mathrm{SE}(\overline{\bar{x}})=\sqrt{\frac{1}{n}\left(s^{2}\right)}
$$

where $s^{2}=\sum^{n}\left(\bar{x}_{\mathrm{i}}-\overline{\bar{x}}\right)^{2} /(n-1)$ variance among primary unit (stations) means. 

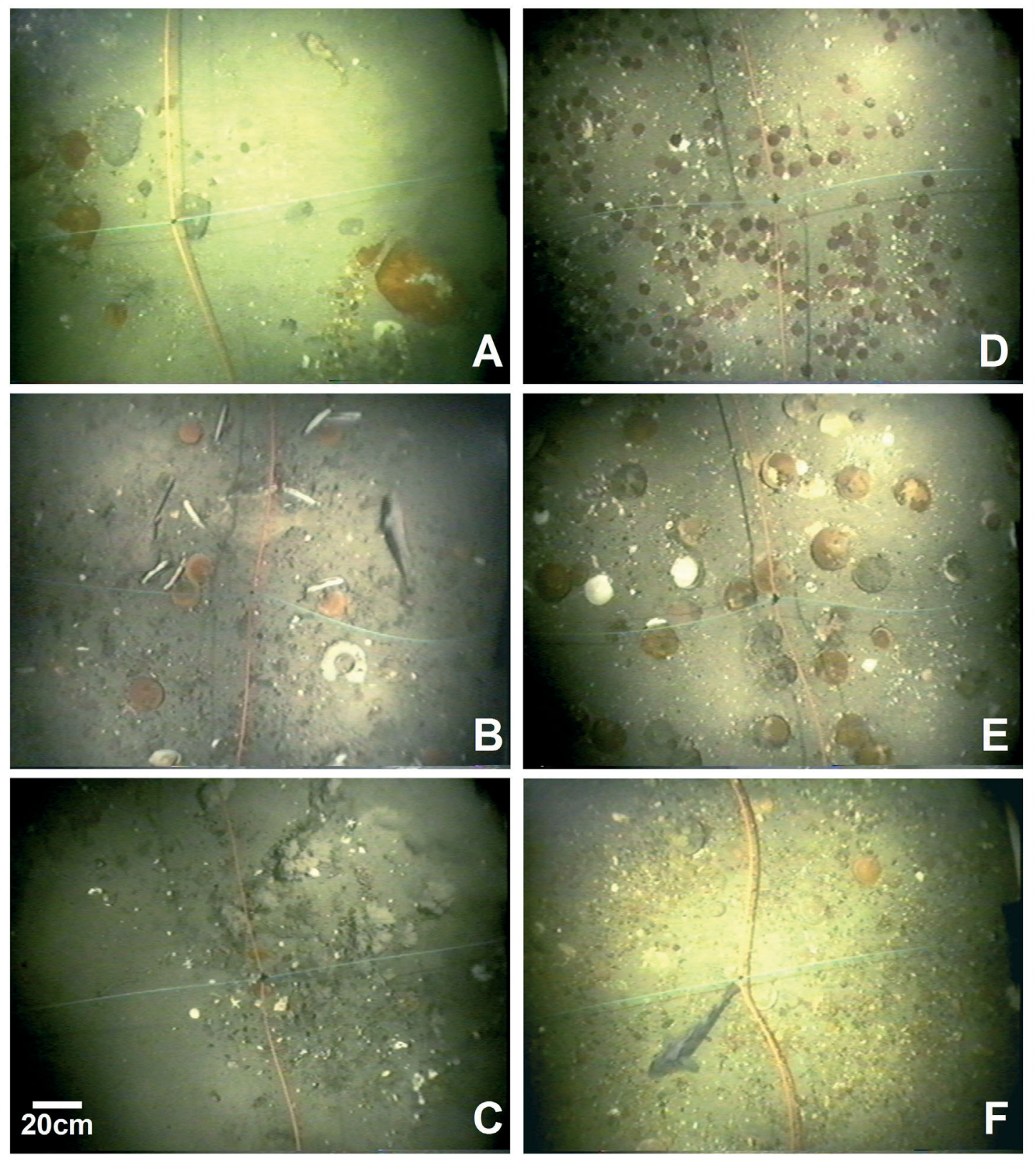

Fig. 4. Video $2.8 \mathrm{~m}^{2}$ quadrat samples for BACI study. (A) Sand/shell debris, granule/pebble, cobble and boulder substrate with sponges (probably Polymatia robusta) and a longhorn sculpin Myoxocephalus octodecemspinosus. (B) Sand/shell debris and granule/pebble substrate with sea scallops Placopecten magellanicus, little skate Raja erinacea, summer flounder Paralichthys dentatus, and Atlantic cod Gadus morhua. (C) Sand/shell debris, granule/pebble and boulder substrate with attached bryozoans/hydrozoans. (D) Sand/shell debris substrate, with sand dollars Echinarachnius parma. (E) Sand/shell debris and granule/ pebble substrate with sea scallops P. magellanicus and bryozoans/hydrozoans. (F) Sand/shell debris and granule/pebble substrate, with sea scallops P. magellanicus, bryozoans/hydrozoans and haddock Melanogrammus aeglefinus

As the sampling fractions were small (hundreds of scallops sampled compared to millions of scallops in the area) the finite population corrections were omitted, simplifying the estimation of the standard error (Cochran 1977). The $95 \%$ confidence intervals were calculated using $\overline{\bar{X}} \pm t_{\alpha} \operatorname{SE}(\overline{\bar{X}})$ (Cochran 1977).
The percent similarity index quantified the differences between benthic communities by comparing the number of taxonomic category present and their relative proportions between areas before and after fishing (Krebs 1989). Each category was standardized as a percentage of the total categories observed. The minimum value was selected for each category 
Table 2. List of Georges Bank species grouped into taxonomic categories; these species have been identified from video recordings, collected from sea scallop tagging experiments, or provided by fishermen; specimens are preserved in authors' laboratory. Note: Filograna implexa is a tube worm but is grouped with bryozoans/hydrozoans as they all create branching plant-like structures on the sea floor. Common molluscan shells making up the substrate category 'shell debris' are also listed

\begin{tabular}{|c|c|c|}
\hline Category & Scientific name & Common name \\
\hline Scallop & Placopecten magellanicus (Gmelin, 1791) & Sea scallop \\
\hline \multirow[t]{5}{*}{ Starfishes } & Solaster endeca (Linnaeus, 1771) & Purple sunstar \\
\hline & Crossaster papposus (Linnaeus, 1767) & Spiny sunstar \\
\hline & Leptasterias polaris (Müller \& Troschel, 1842) & Polar sea star \\
\hline & Asterias spp. & Sea stars \\
\hline & Henricia spp. & Blood star \\
\hline Sand dollars & Echinarachnius parma (Lamarck, 1816) & Sand dollar \\
\hline \multirow{11}{*}{ Bryozoans/hydrozoans } & Flustra foliacea (Linnaeus, 1758) & Bryozoans \\
\hline & Callopora aurita (Hincks, 1877) & Bryozoans \\
\hline & Electra monostachys (Busk, 1854) & Bryozoans \\
\hline & Cribrilina punctata (Hassall, 1841) & Bryozoans \\
\hline & Eucratea loricata (Linnaeus, 1758) & Bryozoans \\
\hline & Tricellaria ternata (Ellis \& Solander, 1786) & Bryozoans \\
\hline & Eudendrium capillare Alder, 1856 & Hydrozoans \\
\hline & Sertularia cupressina Linnaeus, 1758 & Sea cypress hydroid \\
\hline & Sertularia argentea (Linnaeus, 1758) & Squirrel's tail hydroid \\
\hline & Diphasia fallax (Johnston, 1847) & Hydrozoans \\
\hline & Filograna implexa Berkeley, 1828 & Lacy tube worm \\
\hline \multirow[t]{7}{*}{ Sponges } & Suberites ficus (Johnston, 1842) & Fig sponge \\
\hline & Haliclona oculata (Pallas, 1759) & Finger sponge \\
\hline & Halichondria panicea (Pallas, 1766) & Crumb of bread sponge \\
\hline & Cliona celata Grant, 1826 & Boring sponge \\
\hline & Polymastia robusta (Bowerbank, 1860) & Encrusting sponge \\
\hline & Isodictya palmata (Lamarck, 1814) & Palmate sponge \\
\hline & Microciona prolifera (Ellis \& Solander, 1786) & Red beard sponge \\
\hline \multirow[t]{3}{*}{ Crabs } & Homarus americanus H. Milne Edwards, 1837 & American lobster \\
\hline & Cancer irroratus Say, 1817 & Atlantic rock crab \\
\hline & Cancer borealis Stimpson, 1859 & Jonah crab \\
\hline \multirow{3}{*}{ Hermit crabs } & Diogenidae & Left-handed hermit crabs \\
\hline & Paguridae & Right-handed hermit crabs \\
\hline & Parapaguridae & Deep water hermit crabs \\
\hline Eel pout & Zoarces americanus (Bloch \& Schneider, 1801) & Ocean pout \\
\hline \multirow[t]{7}{*}{ Flounder } & Paralichthys dentatus (Linnaeus, 1766) & Summer flounder \\
\hline & Paralichthys oblongus (Mitchill, 1815) & Fourspot flounder \\
\hline & Scophthalmus aquosus (Mitchill, 1815) & Windowpane \\
\hline & Pseudopleuronectes americanus (Walbaum, 1792) & Winter founder \\
\hline & Limanda ferruginea (Storer, 1839) & Yellowtail flounder \\
\hline & Glyptocephalus cynoglossus (Linnaeus, 1758) & Witch flounder \\
\hline & Trinectes maculatus (Bloch \& Schneider, 1801) & Hogchoaker \\
\hline Haddock & Melanogrammus aeglefinus (Linnaeus, 1758) & Haddock \\
\hline \multirow{2}{*}{ Hake } & Merluccius bilinearis (Mitchill, 1814) & Silver hake \\
\hline & Urophycis spp. & Red and white hake \\
\hline \multirow{2}{*}{ Sculpins } & Myoxocephalus octodecemspinosus (Mitchill, 1814) & Longhorn sculpin \\
\hline & Prionotus carolinus (Linnaeus, 1771) & Northern sea robin \\
\hline \multirow[t]{3}{*}{ Skates } & Leucoraja erinacea (Mitchill, 1825) & Little skate \\
\hline & Leucoraja ocellata (Mitchill, 1815) & Winter skate \\
\hline & Dipturus laevis (Mitchill, 1818) & Barndoor skate \\
\hline \multirow{13}{*}{ Other fish } & Myxine glutinosa Linnaeus, 1758 & Atlantic hagfish \\
\hline & Scyliorhinus retifer (Garman, 1881) & Chain dogfish \\
\hline & Squalus acanthias Linnaeus, 1758 & Spiny dogfish \\
\hline & Anguilla rostrata (Lesueur, 1817) & American eel \\
\hline & Conger oceanicus (Mitchill, 1818) & Conger eel \\
\hline & Clupea harengus Linnaeus, 1758 & Atlantic herring \\
\hline & Brosme brosme (Ascanius, 1772) & Cusk \\
\hline & Gadus morhua Linnaeus, 1758 & Atlantic cod \\
\hline & Lophius americanus Valenciennes, 1837 & Goosefish \\
\hline & Ammodytes dubius Reinhardt, 1837 & Northern sand lance \\
\hline & Scomber scombrus Linnaeus, 1758 & Atlantic mackerel \\
\hline & Sebastes fasciatus Storer, 1854 & Acadian redfish \\
\hline & Anarhichas lupus Linnaeus, 1758 & Atlantic wolffish \\
\hline \multirow[t]{6}{*}{ Shell debris } & Buccinum undatum Linnaeus, 1758 & Waved whelk \\
\hline & Euspira heros (Say, 1822) & Northern moonsnail \\
\hline & Mercenaria mercenaria (Linnaeus, 1758) & Northern quahog \\
\hline & Modiolus modiolus (Linnaeus, 1758) & Northern horse mussel \\
\hline & Ensis directus Conrad, 1843 & Atlantic jackknife \\
\hline & Placopecten magellanicus (Gmelin, 1791) & Sea scallops \\
\hline
\end{tabular}


from the 2 samples and the values were summed so that $100 \%$ indicated identical samples. This quantitative similarity coefficient of community structure is robust to sample size and species diversity (Krebs 1989).

The counts of fishes and macroinvertebrates in each area were tested for normality and homogeneity of variance; as most of the data sets failed these tests, a $\log (x+1)$ transformation was applied before further analysis (Green 1979, Zar 1996). The optimal BACI design uses a 2-way analysis of variance (2-way ANOVA) where the interaction between site and time is used to statistically detect an impact. However, the 2-way ANOVA is only reliable if densities in the control and impact areas are equal. This is rarely the case in marine field studies, and the statistics involved to deal with inequality are complex and controversial (for example see Black \& Miller [1991, 1994] and Rangeley [1994]). Several researchers have suggested using only graphs and tables to indicate environmental impacts, while others recommend statistical tests which are usually limited to Student's t-tests and 1-way ANOVAs (Green 1979, StewartOaten et al. 1986, Underwood 1994). Although densities and substrates in our experimental areas were similar they were not equal, and this hampered the use of 2-way ANOVAs. Therefore, we graphed the observed densities to see if there were shifts that suggested impacts from fishing. We used 1-way ANOVAs to test the significance of shifts in mean individuals $\mathrm{m}^{-2}$ within each taxonomic category between surveys for each area. Shifts in sediment composition were compared using chi-squared tests.

\section{RESULTS}

\section{Expt I}

Before vs. after: control area

(September 1999 vs. July 2001)

We observed 10 categories of fishes and macroinvertebrates in the control area in 1999, and 13 in 2001 (Table 3). The sea scallop and starfishes comprised 90.3 and $94.4 \%$ of all individuals in 1999 and 2001, respectively. Mean densities of the sea scallop significantly increased from 0.59 to 0.99 individuals $\mathrm{m}^{2}$, while those of starfishes decreased from 0.10 to 0.02 individuals $\mathrm{m}^{2}$ (Figs. $5 \& 6$, Table 4). Bryozoans/ hydrozoans, hermit crabs and sponges increased in density (Fig. 5 \& 6, Table 4). The similarity index for all categories was $83.8 \%$ (Table 3 ).

The sediment composition differed significantly between 1999 and $2001\left(\chi^{2}=24.3\right.$, df $=3$, p = <0.001,
Table 3. Percent similarity index for epibenthic community observed in Expt I on Georges Bank. Lines indicate survey years used to calculate the \% similarity index

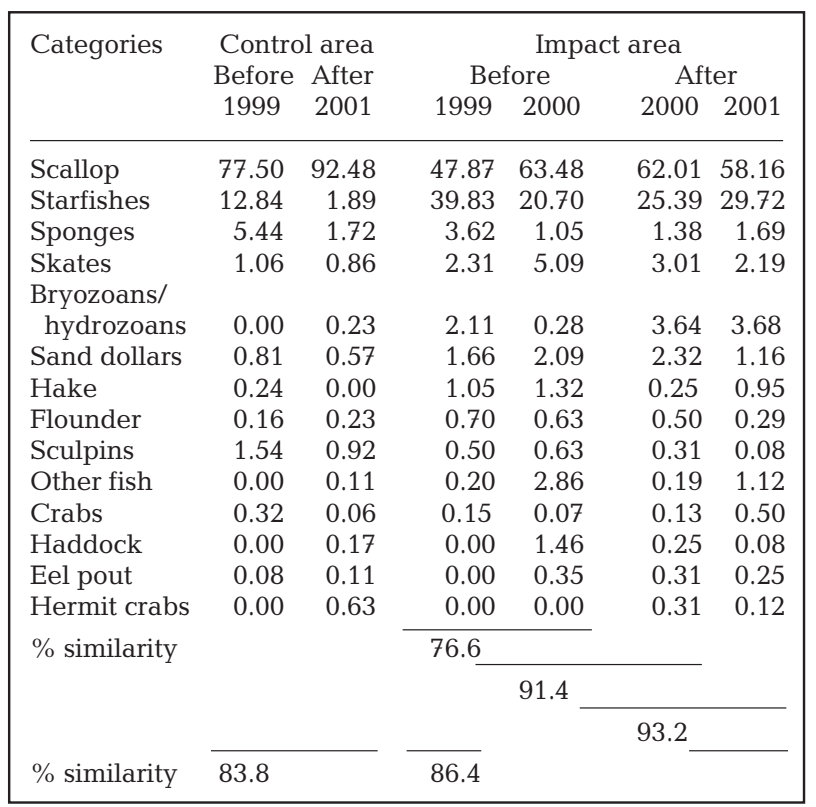

power 0.050:0.995). Granule/pebble substrate increased from 55.2 to $67.5 \%$, cobble decreased from 22.2 to $11.3 \%$, and sand/shell debris and boulders remained the same (Fig. 7). The sediment composition percent similarity index was $87.4 \%$.

Before vs. after: impact area

(July 1999 vs. July 2001)

Approximately $8.5 \%$ of the sea scallops in the impact area were harvested between 15 August and 14 October 2000 (Table 1). In 1999, 11 categories of fishes and macroinvertebrates were observed in the impact area while 14 were observed in 2001 (Table 3). Sea scallops and starfishes represented 87.7 and $87.9 \%$ of all individuals in 1999 and 2001, respectively. Mean sea scallop density significantly increased from 0.42 to 0.63 individuals $\mathrm{m}^{-2}$ (Figs. $5 \& 6$, Table 4). Density of bryozoans/hydrozoans and other fishes significantly increased, while that of sculpins and sponges decreased (Figs. 5 \& 6, Table 3). The similarity index for all categories was $86.4 \%$ (Table 3 ).

The sediment composition differed significantly $\left(\chi^{2}=\right.$ 100.9, df $=3, \mathrm{p}=<0.001$, power 0.050:1.000). Sand/ shell debris increased from 51.9 to $74.4 \%$, granule/ pebble substrate decreased from 36.9 to $20.4 \%$, cobble decreased from 8.1 to $1.0 \%$, and boulders remained the same (Fig. 7). The sediment composition percent similarity index was $76.4 \%$. 

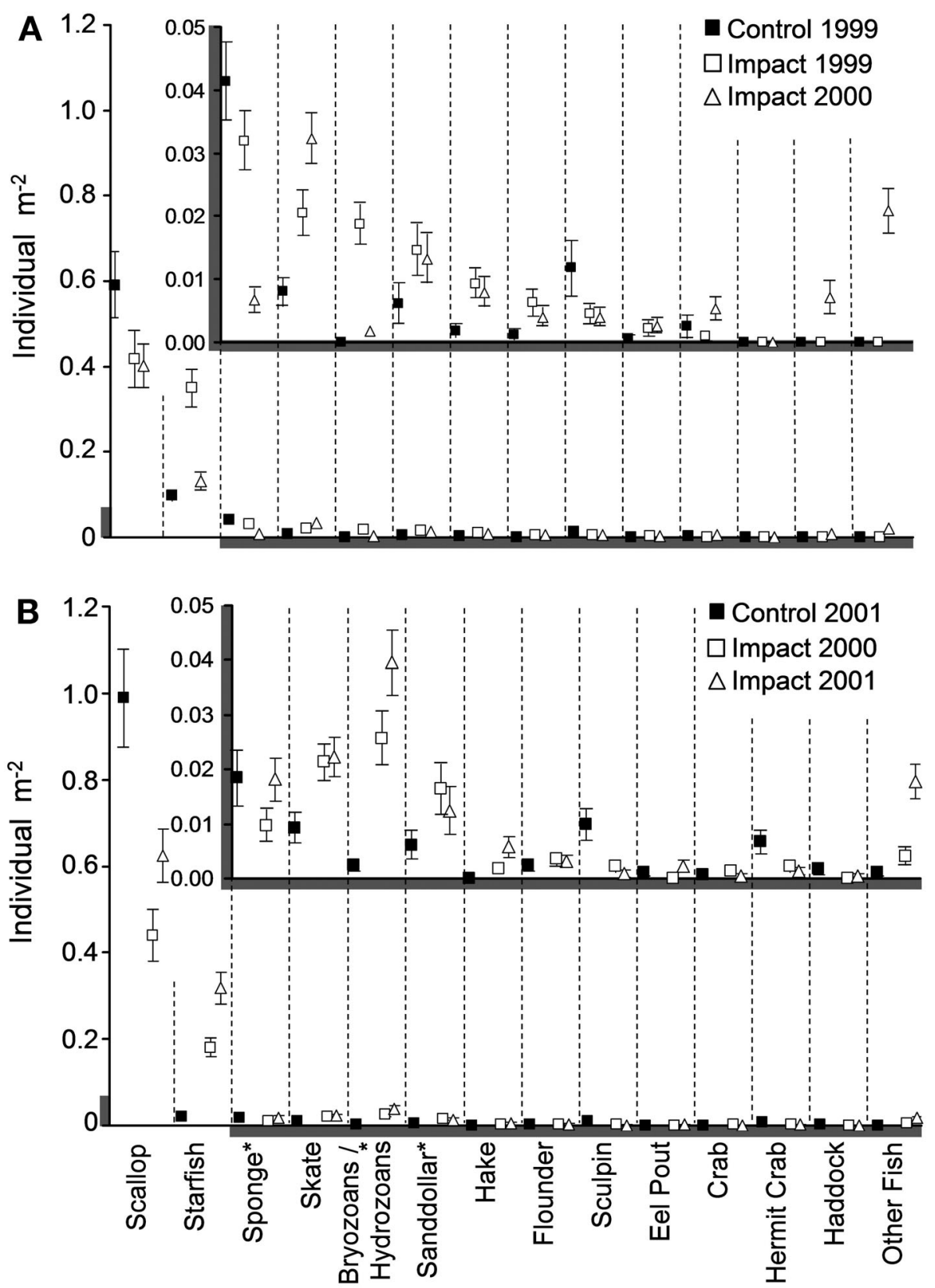

Fig. 5. Mean $\left( \pm \mathrm{SE}\right.$ ) individuals $\mathrm{m}^{-2}$ for taxonomic categories observed (A) before and (B) after sea scallop exemption fishery in Expt I on Georges Bank. Thicker portions of axes indicate portions of axes that have been enlarged in insets. ${ }^{*}$ Significant difference at 0.05

\section{Temporal variations}

Because of prohibitively bad weather in late autumn 2000, we were unable to sample the control area; therefore we had to use the 2001 survey to fulfill the BACI design. Short-term fishing impacts may not have been detected. However, we were able to survey the impact area just prior to and just after the fishery, providing information on the short term shifts in faunal densities and sediment composition (Table 1).
Before vs. before: impact area

(July 1999 vs. August 2000)

The number of fishes and macroinvertebrate categories increased from 11 to 13 from the 1999 to the 2000 surveys (Table 3), with the sea scallop and starfishes comprising 87.7 and $84.2 \%$ of all individuals, respectively. Numbers of starfishes, bryozoans/hydrozoans and sponges significantly decreased, while those of skates, haddock, 'other fish' and crabs signifi- 


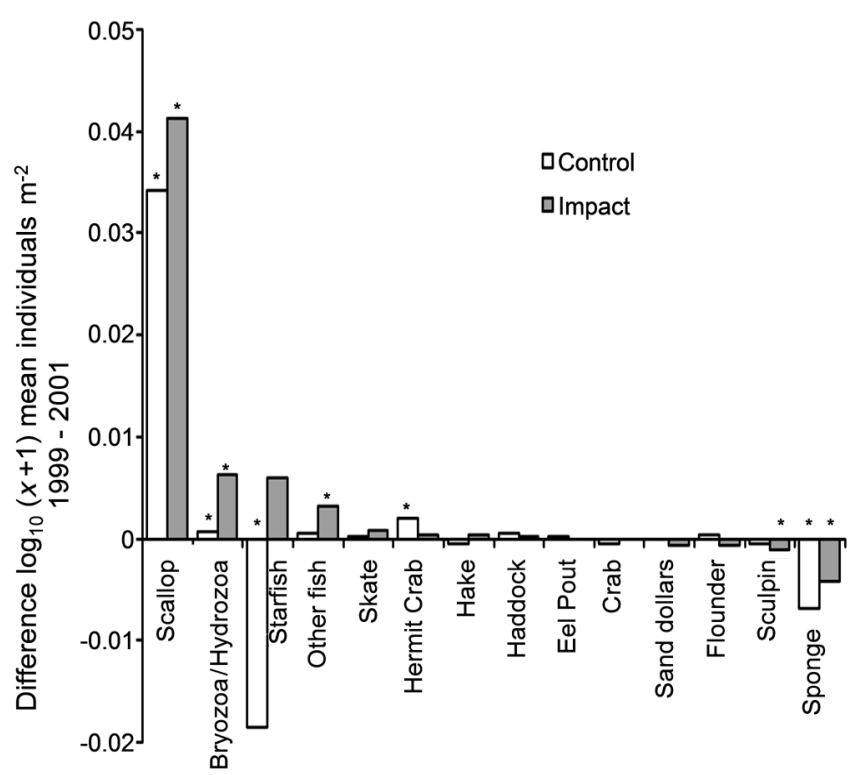

Fig. 6. Difference in mean densities for taxonomic categories observed in Expt I control (CAII) and in impact (NLCA) areas before (1999) and after (2001) the limited fishing event; data are $\log (x+1)$-transformed. * Significant difference at $\mathrm{p}=0.05$

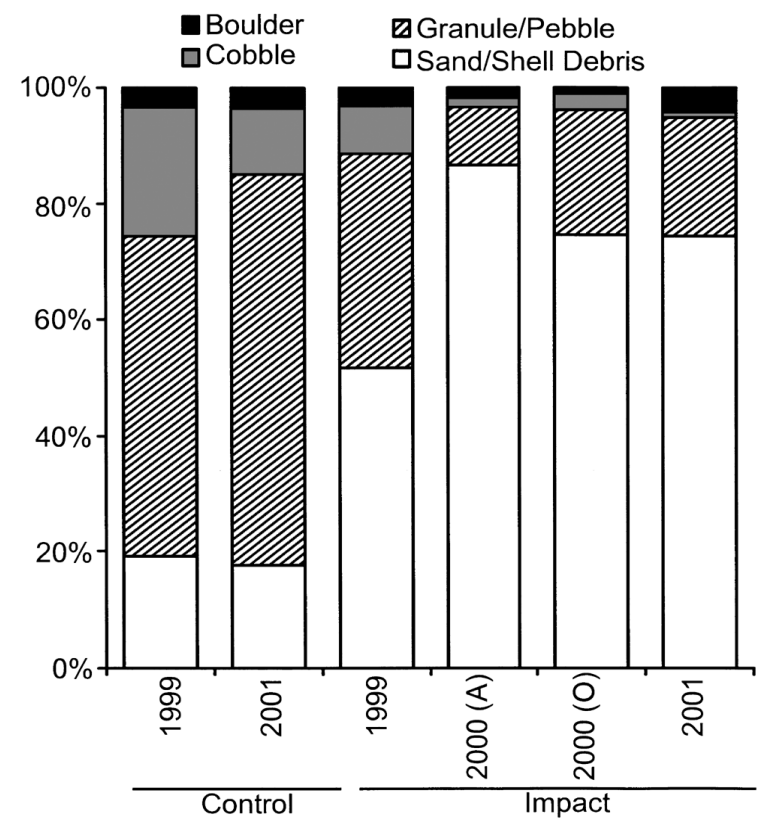

Fig. 7. Sediment composition in control and impact areas in Expt I observed from 1999 to 2001 . Sand $=0.0625$ to $2.0 \mathrm{~mm}$, granule/pebble $=2.0$ to $64.0 \mathrm{~mm}$, cobble $=64.0$ to $256.0 \mathrm{~mm}$ and boulders > $256.0 \mathrm{~mm}$ particle diameter. A: August; O: October

Table 4. Comparison of mean number of individuals $\mathrm{m}^{-2}$ within each taxonomic category in Expts I and II before (1999) and after (2001) fishery, using 1-way ANOVA; data are $\log (x+1)$-transformed; all taxonomic categories were tested but only significant results are presented here. Power is beta, with alpha set at 0.05

\begin{tabular}{|c|c|c|c|c|c|c|c|}
\hline \multicolumn{2}{|l|}{ Categories } & df & SS & MS & $F$ & $\mathrm{p}$ & Power \\
\hline \multicolumn{8}{|l|}{ Expt I } \\
\hline \multicolumn{8}{|c|}{ Control area (Sep 1999 vs. Jul 2001) } \\
\hline \multirow[t]{2}{*}{ Sea scallop } & Between groups & 1 & 0.074 & 0.074 & 6.637 & 0.011 & 0.659 \\
\hline & Residual & & 249 & 2.763 & 0.011 & & \\
\hline \multirow[t]{2}{*}{ Bryozoans/hydrozoans } & Between groups & 1 & 0.000 & 0.000 & 4.066 & 0.450 & 0.399 \\
\hline & Residual & & 249 & 0.002 & 0.000 & & \\
\hline \multirow[t]{2}{*}{ Starfishes } & Between groups & 1 & 0.021 & 0.021 & 34.180 & $<0.001$ & 1.000 \\
\hline & Residual & & 249 & 0.156 & 0.001 & & \\
\hline \multirow[t]{2}{*}{ Hermit crabs } & Between groups & 1 & 0.000 & 0.000 & 9.891 & 0.002 & 0.862 \\
\hline & Residual & & 249 & 0.007 & 0.000 & & \\
\hline \multirow[t]{2}{*}{ Sponges } & Between groups & 1 & 0.003 & 0.003 & 8.256 & 0.004 & 0.778 \\
\hline & Residual & & 249 & 0.091 & 0.000 & & \\
\hline \multicolumn{8}{|c|}{ Impact area (Jul 1999 vs. Jul 2001) } \\
\hline \multirow[t]{2}{*}{ Sea scallop } & Between groups & 1 & 0.149 & 0.149 & 21.162 & $<0.001$ & 0.998 \\
\hline & Residual & & 346 & 2.430 & 0.007 & & \\
\hline \multirow[t]{2}{*}{ Bryozoans/hydrozoans } & Between groups & 1 & 0.003 & 0.003 & 9.577 & 0.002 & 0.849 \\
\hline & Residual & & 346 & 0.124 & 0.000 & & \\
\hline \multirow[t]{2}{*}{ Other fishes } & Between groups & 1 & 0.001 & 0.001 & 15.549 & $<0.001$ & 0.980 \\
\hline & Residual & & 346 & 0.019 & 0.000 & & \\
\hline \multirow[t]{2}{*}{ Sculpins } & Between groups & 1 & 0.000 & 0.000 & 4.748 & 0.030 & 0.476 \\
\hline & Residual & & 346 & 0.007 & 0.000 & & \\
\hline \multirow[t]{2}{*}{ Sponges } & Between groups & 1 & 0.001 & 0.001 & 5.095 & 0.025 & 0.514 \\
\hline & Residual & & 346 & 0.101 & 0.000 & & \\
\hline \multirow{2}{*}{\multicolumn{8}{|c|}{$\begin{array}{l}\text { Expt II } \\
\text { Impact area (Aug } 2000 \text { vs. Jun 2001) }\end{array}$}} \\
\hline & & & & & & & \\
\hline \multirow[t]{2}{*}{ Sea scallop } & Between groups & 1 & 0.016 & 0.016 & 3.502 & 0.063 & 0.333 \\
\hline & Residual & & 219 & 0.982 & 0.005 & & \\
\hline \multirow[t]{2}{*}{ Bryozoans/hydrozoans } & Between groups & 1 & 0.000 & 0.000 & 6.115 & 0.014 & 0.613 \\
\hline & Residual & & 219 & 0.020 & 0.000 & & \\
\hline
\end{tabular}


cantly increased (Figs. $5 \&$ 8, Table 5). The similarity index for all categories was $76.6 \%$, the lowest value measured for any of the areas surveyed (Table 3 ).

The sediment composition differed significantly $\left(\chi^{2}=\right.$ 200.8, df $=3, \mathrm{p}=<0.001$, power 0.050:1.000). Sand/ shell debris increased from 51.9 to $86.6 \%$, while granule/pebble substrate decreased from 36.9 to $10.2 \%$ and cobble from 8.1 to $1.6 \%$ (Fig. 7). The sediment composition percent similarity index was $65.3 \%$, the lowest value observed for any area.
Before vs. after: impact area

(August 2000 vs. October 2000)

This area was surveyed immediately before and after the limited short-term fishery in August and October 2000 (Table 1). The number of categories increased from 13 to 14 (Table 3). The sea scallop and starfishes comprised 84.2 and $87.4 \%$ of all individuals in August and October, respectively. Mean density of the sea scallop were similar, 0.40 to 0.44 individuals $\mathrm{m}^{-2}$

Table 5. Comparison of mean number of individuals $\mathrm{m}^{-2}$ indicating temporal variations within epibenthic communities of Expts I and II; data are $\log (x+1)$-transformed. The 1-way ANOVAs were preformed on surveys chronologically; all taxonomic categories were tested but only significant results are presented here. Power is beta, with alpha set at 0.05

\begin{tabular}{|c|c|c|c|c|c|c|c|}
\hline Categories & & df & SS & MS & $F$ & $\mathrm{p}$ & Power \\
\hline \multicolumn{8}{|l|}{ Expt I } \\
\hline \multicolumn{8}{|c|}{ Before vs. before: impact area (Jul 1999 vs. Aug 2000) } \\
\hline \multirow[t]{2}{*}{ Starfishes } & Between groups & 1 & 0.065 & 0.065 & 19.838 & $<0.001$ & 0.996 \\
\hline & Residual & & 346 & 1.129 & 0.003 & & \\
\hline \multirow{2}{*}{ Bryozoans/hydrozoans } & Between groups & 1 & 0.002 & 0.002 & 26.725 & $<0.001$ & 1.000 \\
\hline & Residual & & 346 & 0.029 & 0.000 & & \\
\hline \multirow[t]{2}{*}{ Other fish } & Between groups & 1 & 0.002 & 0.002 & 26.402 & $<0.001$ & 1.000 \\
\hline & Residual & & 346 & 0.027 & 0.000 & & \\
\hline \multirow[t]{2}{*}{ Sponges } & Between groups & 1 & 0.005 & 0.005 & 25.311 & $<0.001$ & 1.000 \\
\hline & Residual & & 346 & 0.069 & 0.000 & & \\
\hline \multirow[t]{2}{*}{ Skates } & Between groups & 1 & 0.001 & 0.001 & 5.179 & 0.023 & 0.522 \\
\hline & Residual & & 346 & 0.071 & 0.000 & & \\
\hline \multirow[t]{2}{*}{ Crabs } & Between groups & 1 & 0.000 & 0.000 & 5.751 & 0.017 & 0.580 \\
\hline & Residual & & 346 & 0.009 & 0.000 & & \\
\hline \multirow[t]{2}{*}{ Haddock } & Between groups & 1 & 0.001 & 0.001 & 11.830 & $<0.001$ & 0.926 \\
\hline & Residual & & 346 & 0.016 & 0.000 & & \\
\hline \multicolumn{8}{|c|}{ Before vs. after: impact area (Aug 2000 vs. Oct 2000) } \\
\hline \multirow[t]{2}{*}{ Starfishes } & Between groups & 1 & 0.010 & 0.010 & 4.336 & 0.038 & 0.431 \\
\hline & Residual & & 346 & 0.822 & 0.002 & & \\
\hline \multirow[t]{2}{*}{ Bryozoans/hydrozoans } & Between groups & 1 & 0.005 & 0.005 & 24.060 & $<0.001$ & 0.999 \\
\hline & Residual & & 346 & 0.065 & 0.000 & & \\
\hline \multirow[t]{2}{*}{ Other fish } & Between groups & 1 & 0.002 & 0.002 & 27.819 & $<0.001$ & 1.000 \\
\hline & Residual & & 346 & 0.027 & 0.000 & & \\
\hline \multirow{2}{*}{ Skates } & Between groups & 1 & 0.001 & 0.001 & 5.130 & 0.024 & 0.517 \\
\hline & Residual & & 346 & 0.066 & 0.000 & & \\
\hline \multirow{2}{*}{ Hake } & Between groups & 1 & 0.000 & 0.000 & 7.674 & 0.006 & 0.740 \\
\hline & Residual & & 346 & 0.016 & 0.000 & & \\
\hline \multirow[t]{2}{*}{ Haddock } & Between groups & 1 & 0.000 & 0.000 & 6.491 & 0.011 & 0.648 \\
\hline & Residual & & 346 & 0.018 & 0.000 & & \\
\hline Eel pout & Between groups & 1 & 0.000 & 0.000 & 6.126 & 0.014 & 0.615 \\
\hline & Residual & & 346 & 0.003 & 0.000 & & \\
\hline Crabs & Between groups & 1 & 0.000 & 0.000 & 4.340 & 0.038 & 0.431 \\
\hline & Residual & & 346 & 0.009 & 0.000 & & \\
\hline Hermit crabs & Between groups & 1 & 0.000 & 0.000 & 3.877 & 0.050 & 0.378 \\
\hline & Residual & & 346 & 0.003 & 0.000 & & \\
\hline After vs. after: impact a & rea (Oct 2000 vs. J & & & & & & \\
\hline Scallop & Between groups & 1 & 0.105 & 0.105 & 14.723 & $<0.001$ & 0.943 \\
\hline & Residual & & 346 & 2.463 & 0.007 & & \\
\hline Starfishes & Between groups & 1 & 0.043 & 0.043 & 11.911 & $<0.001$ & 0.928 \\
\hline & Residual & & 346 & 1.260 & 0.004 & & \\
\hline Other fish & Between groups & 1 & 0.001 & 0.001 & 16.797 & $<0.001$ & 0.988 \\
\hline & Residual & & 346 & 0.019 & 0.000 & & \\
\hline Hake & Between groups & 1 & 0.001 & 0.001 & 9.957 & 0.002 & 0.865 \\
\hline & Residual & & 346 & 0.019 & 0.000 & & \\
\hline Expt II & & & & & & & \\
\hline Before vs. before: cont & ol area (Jul 1999 & 200 & & & & & \\
\hline Starfishes & Between groups & 1 & 0.020 & 0.020 & 10.034 & 0.002 & 0.862 \\
\hline & Residual & & 90 & 0.176 & 0.002 & & \\
\hline Bryozoans/hydrozoans & Between groups & 1 & 0.001 & 0.001 & 4.614 & 0.034 & 0.456 \\
\hline & Residual & & 90 & 0.017 & 0.000 & & \\
\hline Hake & Between groups & 1 & 0.001 & 0.001 & 8.291 & 0.005 & 0.773 \\
\hline & Residual & & 90 & 0.014 & 0.000 & & \\
\hline Before vs. before: impa & ct area (Jul $1999 \mathrm{v}$ & 200 & & & & & \\
\hline Other fish & Between groups & 1 & 0.000 & 0.000 & 7.350 & 0.007 & 0.715 \\
\hline & Residual & & 199 & 0.010 & 0.000 & & \\
\hline Hake & Between groups & 1 & 0.002 & 0.002 & 16.881 & $<0.001$ & 0.988 \\
\hline & Residual & & 199 & 0.026 & 0.000 & & \\
\hline
\end{tabular}




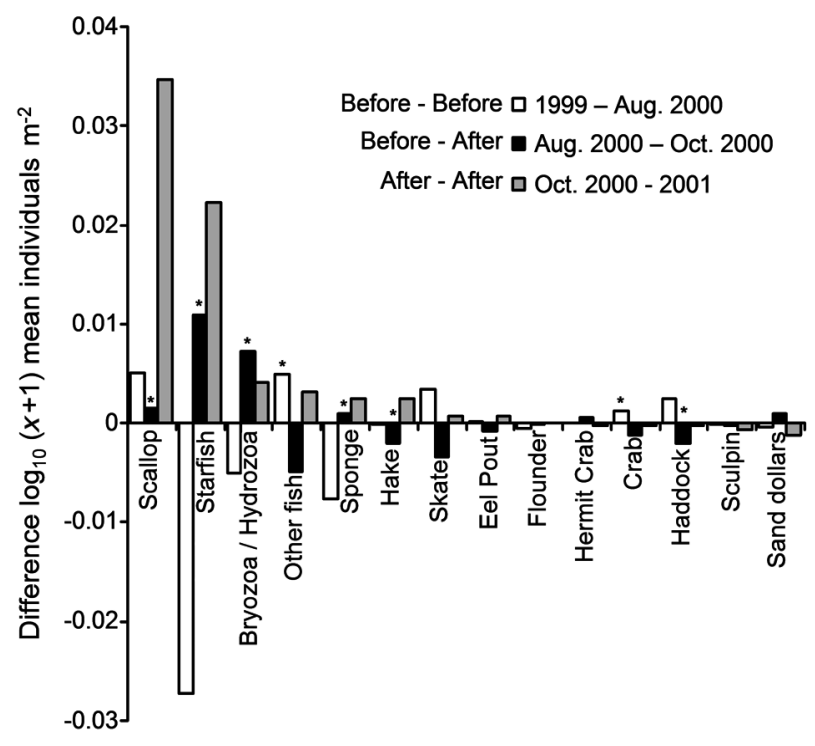

Fig. 8. Difference in mean densities for taxonomic categories observed in Expt I impact area (NLCA) from 1999 to 2000 (undisturbed), August 2000 to October 2000 (the fishing event occurred between these 2 surveys) and October 2000 and 2001 (undisturbed); data are $\log (x+1)$-transformed. * Significant difference at $\mathrm{p}=0.05$

(Figs. 5 \& 8, Table 5). Density of starfishes, bryozoans/ hydrozoans and hermit crabs significantly increased, while that of skates, hake, haddock, eel pout, 'other fish' and crabs decreased (Figs. 5 \& 8, Table 5). The similarity index for all categories was high at $91.4 \%$ (Table 3).

The sediment composition differed significantly $\left(\chi^{2}=\right.$ 37.7, df = 3, $\mathrm{p}=<0.001$, power 0.050:1.000). Sand/shell debris dominated the substrate but decreased from 86.6 to $74.6 \%$, while the granule/pebble substrate doubled from 10.2 to $21.6 \%$ (Fig. 7). Cobble also doubled from 1.6 to $2.7 \%$. The sediment composition percent similarity index was $87.4 \%$.

After vs. after: impact area

(October 2000 vs. July 2001)

In both October 2000 and 2001, 14 fish and macroinvertebrate categories were observed (Table 2). The sea scallop and starfishes comprised 87.4 and $87.9 \%$ of all individuals. Mean density of sea scallops increased from 0.44 to 0.63 individuals $\mathrm{m}^{-2}$ (Figs. 5 \& 8, Table 5). Starfishes, hake and 'other fish' also significantly increased (Figs. 5 \& 8, Table 5). The similarity index for all categories was the highest observed at $93.2 \%$ (Table 3).

The sediment composition differed significantly $\left(\chi^{2}=\right.$ 17.7, df $=3, \mathrm{p}=<0.001$, power 0.050:1.000). However, sand/shell debris and granule/pebble cover were simi- lar between years (Fig. 7). Cobble decreased to $1.0 \%$ and boulder substrate increased to $4.2 \%$. The sediment composition percent similarity index between years was very high at $97.0 \%$.

\section{Expt II}

Before vs. after: control area

(August 2000 and June 2001)

In the control area, 7 fish and macroinvertebrate categories were observed in both 2000 and 2001 (Table 6). The sea scallop and starfishes comprised 93.0 and $93.1 \%$ of all individuals in 2000 and 2001, respectively. The mean densities for each category were similar between 2000 and 2001 (Figs. 9 \& 10, Table 4). The similarity index for all categories was very high at $96.9 \%$ (Table 6).

The sediment composition differed significantly $\left(\chi^{2}=\right.$ 16.5, df $=2, \mathrm{p}=<0.001$, power 0.050:0.972). Granule/ pebble substrate doubled from 25.0 to $49.5 \%$, cobble decreased from 10.9 to $1.6 \%$ and sand/shell debris decreased from 61.5 to $47.8 \%$ (Fig. 11). The sediment composition percent similarity index was $75.5 \%$.

\section{Before vs. after: impact area (2000 and 2001)}

In the impact area, 8 fish and macroinvertebrate categories were observed in 2000 and 2001 (Table 6). The sea scallop and starfishes comprised 90.0 and $86.0 \%$ of all individuals in 2000 and 2001, respectively. Most of the 56 million sea scallops harvested during the fishery from 15 October 2000 to 27 February 2001 came from the impact study area and sea scallop densities declined from 0.35 to 0.22 individuals $\mathrm{m}^{-2}$, although the

Table 6. Percent similarity index for epibenthic community observed in Expt II on Georges Bank. Lines indicate survey years used to calculate \% similarity index

\begin{tabular}{|c|c|c|c|c|c|c|}
\hline \multirow{3}{*}{ Categories } & \multicolumn{3}{|c|}{ Control } & \multicolumn{3}{|c|}{ Impact } \\
\hline & \multicolumn{2}{|c|}{ Before } & \multirow{2}{*}{$\begin{array}{l}\text { After } \\
2001\end{array}$} & \multicolumn{2}{|c|}{ Before } & \multirow{2}{*}{$\begin{array}{r}\text { After } \\
2001\end{array}$} \\
\hline & 1999 & 2000 & & 1999 & 2000 & \\
\hline Scallop & 76.64 & 71.84 & 73.93 & 55.65 & 67.81 & 59.46 \\
\hline Starfish & 9.63 & 21.20 & 19.21 & 29.17 & 22.19 & 26.58 \\
\hline Skate & 5.74 & 3.16 & 2.23 & 4.97 & 3.70 & 3.63 \\
\hline Hake & 4.30 & 0.63 & 0.51 & 5.51 & 1.23 & 1.91 \\
\hline Sand dollars & 1.84 & 0.79 & 1.72 & 2.55 & 3.15 & 3.63 \\
\hline Sponge & 1.64 & 0.32 & 0.17 & 0.81 & 1.10 & 0.38 \\
\hline \multirow{4}{*}{$\begin{array}{l}\text { Bryozoans/ } \\
\text { hydrozoans } \\
\text { Flounder } \\
\text { \% similarity }\end{array}$} & 0.20 & 2.06 & 2.23 & 0.67 & 0.41 & 3.44 \\
\hline & 0.00 & 0.00 & 0.00 & 0.67 & 0.41 & 0.96 \\
\hline & \multicolumn{3}{|l|}{86.5} & \multicolumn{2}{|l|}{86.8} & \\
\hline & & & 96.9 & & & $\overline{90.9}$ \\
\hline
\end{tabular}



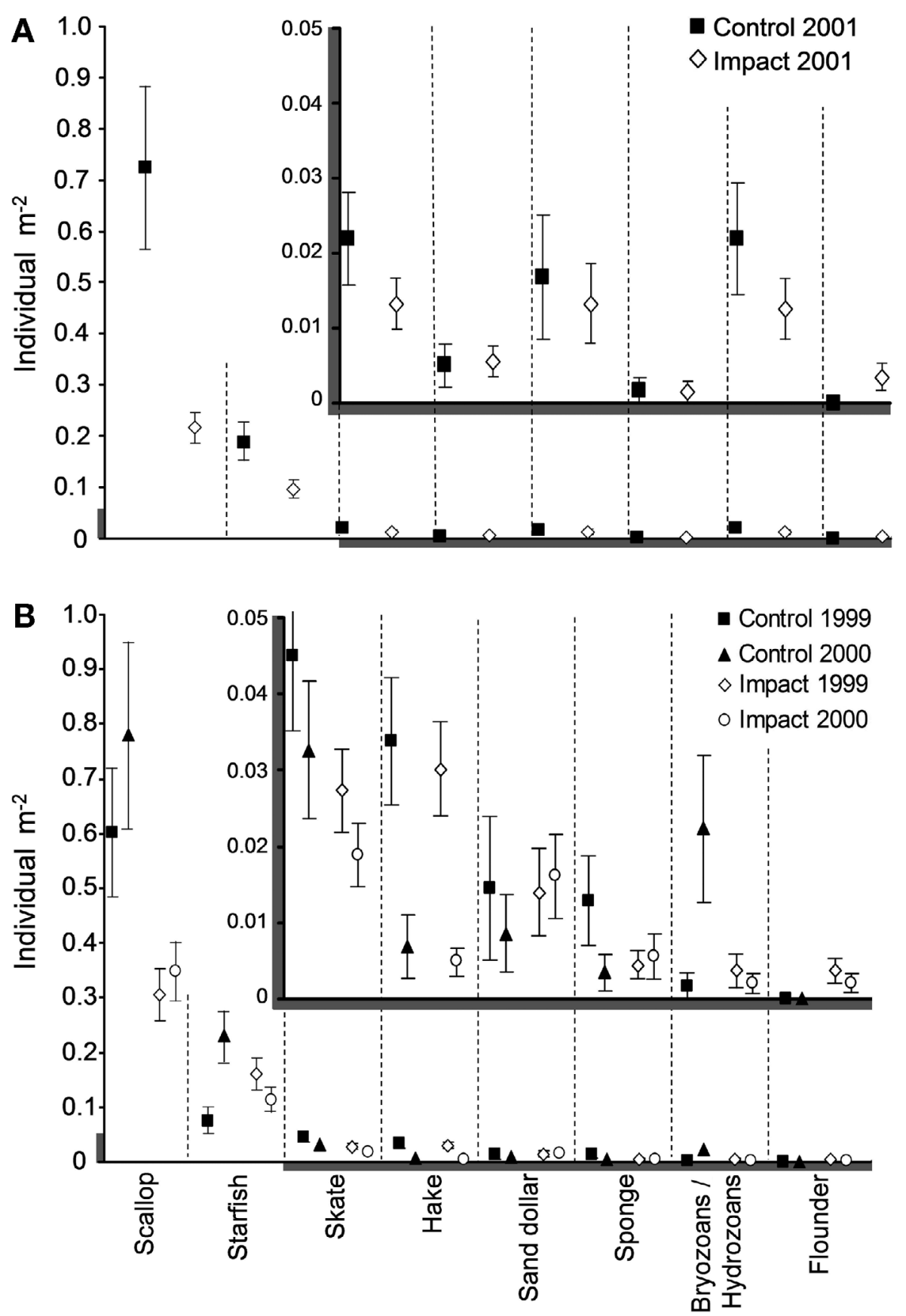

Fig. 9. Means $\left( \pm \mathrm{SE}\right.$ ) individuals $\mathrm{m}^{-2}$ for taxonomic categories observed (A) before and (B) after sea scallop exemption fishery in Expt II on Georges Bank. Thicker portions of axes indicate portions that have been enlarged in insets

difference in densities was not quite significant, since $\mathrm{p}=0.06$ rather than 0.05 (Table 4). Byrozoans/hydrozoans significantly increased and all other categories remained the same (Figs. $9 \& 10$, Table 4). The similarity index for all categories was very high at $90.9 \%$ (Table 6).

The sediment composition was similar between the 2 surveys $\left(\chi^{2}=2.30, \mathrm{df}=2, \mathrm{p}=0.316\right.$, power 0.050:0.243). Sand/shell debris dominated at 88.6 and $79.3 \%$ for
2000 and 2001, respectively. The sediment composition percent similarity index was $87.5 \%$ (Fig. 11).

\section{Temporal variations}

The same stations in both areas were observed in 1999, enabling us to compare temporal shifts in taxonomic categories and sediments with no fishing disturbance. 


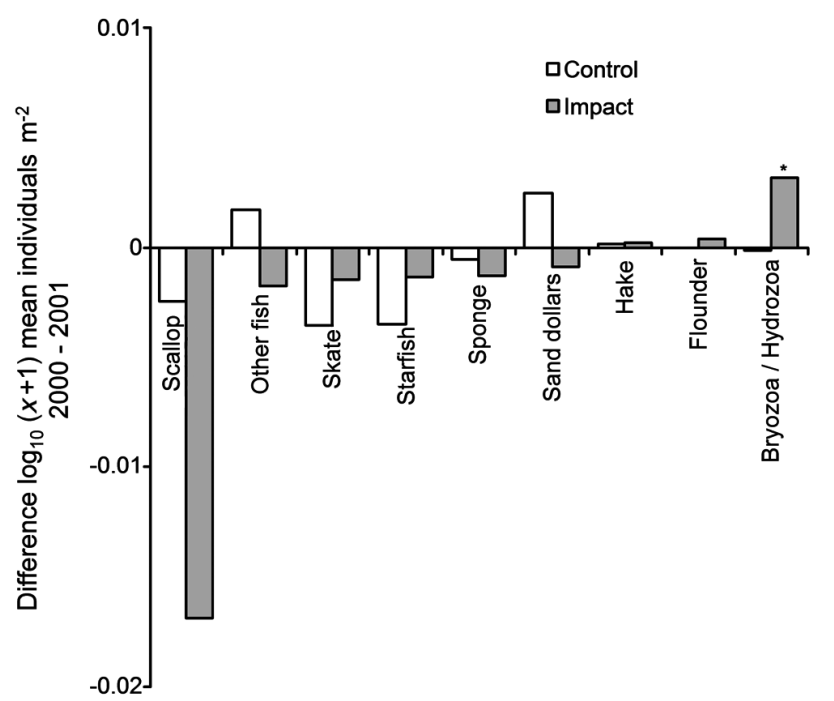

Fig. 10. Difference in mean densities for taxonomic categories observed in Expt II, control (CAIS) and impact (CAIN) areas, before and after limited fishing event; data are $\log (x+1)$ transformed ${ }_{i}$ *Significant difference at $\mathrm{p}=0.05$

Before vs. before: control area

(July 1999 vs. August 2000)

In the control area, 7 fish and macroinvertebrate categories were observed in 1999 and 2000 (Table 6). The sea scallop and starfishes comprised 86.3 and $93.0 \%$ of all individuals. Density of bryozoans/hydrozoans and starfishes significantly increased, while that of hake significantly decreased (Figs. $9 \& 12$, Table 5). The other categories remained similar (Figs. $9 \& 12$, Table 5). The similarity index for all categories was $86.5 \%$ (Table 6).

The sediment composition differed significantly $\left(\chi^{2}=\right.$ 11.7, $\mathrm{df}=2, \mathrm{p}=0.003$, power 0.050:0.886). Granule/pebble substrate decreased from 40.6 to $25.0 \%$, while sand/shell debris increased from 45.0 to $61.5 \%$ (Fig. 11). The sediment composition percent similarity index was $80.9 \%$.

Before vs. before: impact area

(July 1999 vs. August 2000)

In the impact area, 8 fish and macroinvertebrate categories were observed in both 1999 and 2000 (Table 6). 'Other fish' significantly increased in numbers, while hake significantly decreased and all other categories remained the same (Figs. $9 \& 12$, Table 5). The similarity index for all categories was very high at $86.8 \%$.

The sediment composition differed significantly $\left(\chi^{2}=\right.$ 20.5, df $=2, \mathrm{p}=<0.001$, power 0.050:0.993). Sand/shell debris was the dominant substrate at 82.5 and $88.6 \%$, while granule/pebble decreased from 15.7 to $6.9 \%$ for 1999 and 2001, respectively (Fig. 11). The sediment composition percent similarity index was $91.2 \%$.

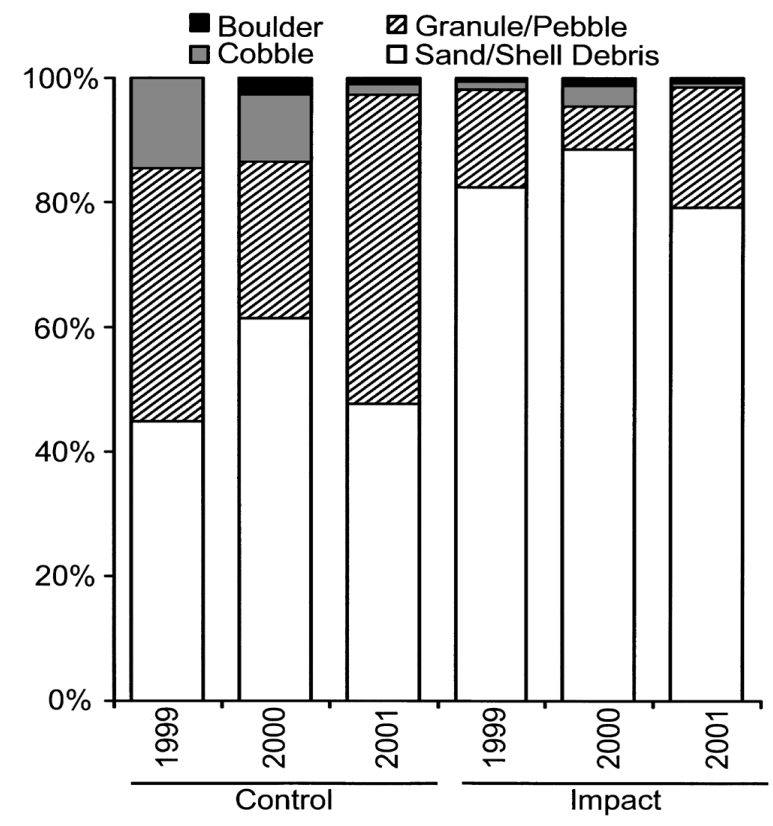

Fig. 11. Sediment composition in control and impact areas in Expt II observed from 1999 to 2001 . Sand $=0.0625$ to $2.0 \mathrm{~mm}$, granule/pebble $=2.0$ to $64.0 \mathrm{~mm}$, cobble $=64.0$ to $256.0 \mathrm{~mm}$ and boulders $>256.0 \mathrm{~mm}$ particle diameter

\section{DISCUSSION}

Changes in the number of fish and macroinvertebrate categories and the density of individuals within each category in the areas impacted by the limited short-term sea scallop fishery were similar to changes in the control areas that remained closed to fishing. Further, sediment composition shifted between surveys more than epibenthic faunal composition.

In the control and impact areas of Expt I the number of taxonomic categories increased from before to after the limited fishery. The sea scallop and starfishes comprised over $87 \%$ of all fish and macroinvertebrate categories. The numbers of individuals within many of the categories did not change significantly. Sea scallops and bryozoans/hydrozoans increased in both areas. Only sponges increased in the control area and decreased in the impact area. The similarity index suggested that shifts in the numbers of categories and the density of each category were similar. However, the sediment composition in both the control and impact areas shifted significantly. The largest shift in both sediment composition and taxonomic category occurred in the impact area between 1999 and 2000 before the limited fishery.

In the control and impact areas of Expt II the number of taxonomic categories remained the same before and after the limited fishery. The numbers of individuals within categories were similar, except for bryozoans/ hydrozoans, which increased significantly in the 


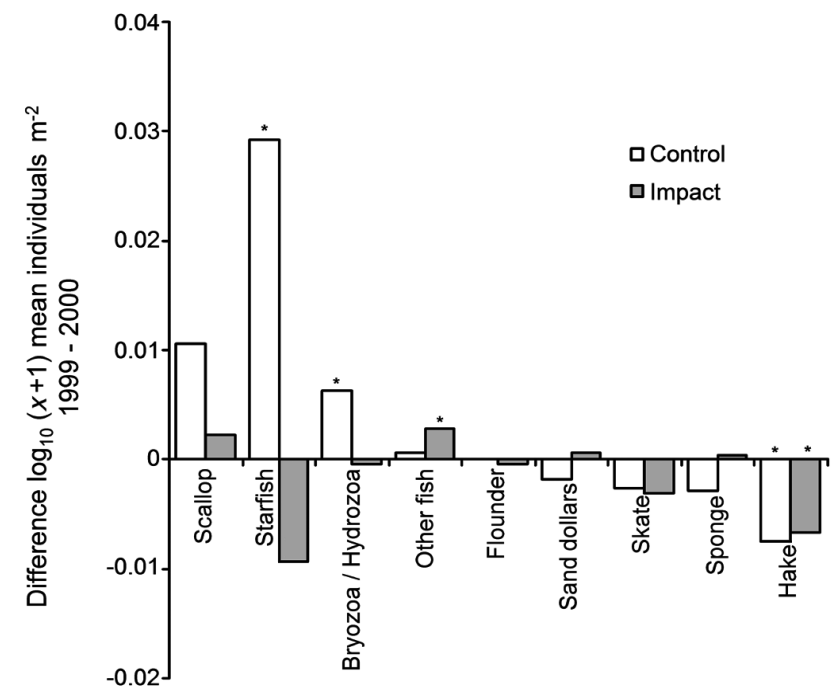

Fig. 12. Difference in mean densities for taxonomic categories observed in Expt II, control (CAIS) and impact (CAIN) areas, from 1999 to 2000 (undisturbed); data are $\log (x+1)$ transformed $_{i}{ }^{*}$ Significant difference at $p=0.05$

impact area. The similarity index for all categories suggested a greater variation in the impact area than in the control area, but both indices indicated a high degree of similarity before and after the limited fishery. The sediment composition shifted significantly in the control area but not in the impact area.

As the sediment composition varied more than the benthic community structure, it appears that the epibenthic community associated with sea scallop aggregations is adapted to living in a dynamic environment. Sea scallops are strongly associated with sand/granule/pebble substrate, which in turn is associated with areas of high tidal energy (Thouzeau et al. 1991, Stokesbury 2002). Tidally induced bottom currents and storm events can be strong in all our study locations, reaching speeds above $30 \mathrm{~cm} \mathrm{~s}^{-1}$ (Brown \& Moody 1987, Butman 1987a,b, Butman \& Beardsley 1987). Animals such as sea scallops have adapted to this unstable environment, for example, juveniles can attach to pebbles or larger particles using byssal threads, allowing them to remain stationary. The adult sea scallop's ability to swim, form depressions in sand/granule/pebble substrates and orient itself to avoid sediments entering the pallial gap reduces the effects of these currents, allowing it to persist in dynamic areas (Baird 1954, Caddy 1968, Dadswell \& Weihs 1990, Cheng \& Demont 1996, Stokesbury \& Himmelman 1996, Stokesbury 2002, Stokesbury et al. 2004). Further, the sea scallop shell appears to be the most stable surface in sand/granule/pebble sediments and provides a structure to which sessile epifauna attach; for example, 49 species were identified on scallop shells in the Bay of Fundy (Kenchington 2000).
Sediment communities are continually exposed to natural disturbance at various scales (Hall 1994, Jennings \& Kaiser 1998). Veale et al. (2000) found that natural disturbances in sediment communities were sufficient to maintain low fishing-effort areas at an intermediate level of total disturbance, so that species diversity decreased only with increasing fishing effort. Sand habitats on Georges Bank exposed to natural disturbances may recover from fishing gear impact in a relatively short period of time: less than $1 \mathrm{yr}$ (Lindholm et al. 2004).

The first controlled experiments (BACI) to assess the impact of scallop dredging on a commercial spatial scale were performed in Australia using a 'Peninsula' dredge (fitted with scraper and cutter bars that did not extend below the level of the skids) (Currie \& Parry 1996, 1999). In the 1996 study, a 20 to $30 \%$ decrease in the abundance of most species was detected after fishing, but the impact was undetectable 6 mo later after recruitment for most species. In the 1999 study conducted on soft substrates, changes in the benthic community were small and damage to bycatch species was slight.

Our findings differ from several studies that suggest that sea scallop harvesting severely impacted the sea floor. Some studies examined the environmental impacts of the New Bedford scallop dredge by comparing heavily fished areas to areas that were never fished (Collie et al. 1997, Collie \& Escanero 2000). These studies may have compared different benthic communities, as the sea scallop is strongly associated with sand/granule/pebble substrates, and is the dominant macroinvertebrate in these substrates on Georges Bank but was rare at the control sites in the studies of Collie et al. (1997) and Collie \& Escanero (2000), as indicated by the low fishing effort. Several studies examined the impact of the dredge on the sea floor immediately after the dredge had passed (Caddy 1968, 1971, 1973). However, it is very difficult to expand the effects of a single pass of a dredge to the entire fishery as the fishery is not spatially or temporally uniform and covers a range of environmental conditions.

Many fishing impact studies have used smaller sample sizes and examined disturbances on a smaller spatial scale than our study. Collie \& Escanero (2000) used a total sample area of $17.3 \mathrm{~m}^{2}$ (64, $0.27 \mathrm{~m}^{2}$ still photographs) to survey 5 sites, comparing fished, unfished, shallow and deep habitats (250 $\mathrm{km}^{2}$ total survey area) on Georges Bank. Lindholm et al. (2004) used a total sample area of $12.5 \mathrm{~m}^{2}\left(32,0.39 \mathrm{~m}^{2}\right.$ still photographs) to determine the abundance of common microhabitats inside and outside CA II on Georges Bank in 1999; the sea scallop was only rarely detected in the closed area with their sampling design, although it is the dominant macroinvertebrate (Stokesbury et al. 2004) in this area, suggesting their analyses focused on a fine scale. Our sample 
size and number $\left(12.9 \mathrm{~m}^{2}\right.$ per station, 1379 stations, $17789 \mathrm{~m}^{2}$ total sample area, $1118 \mathrm{~km}^{2}$ survey area) had a higher sampling frequency based on a target precision of 5 to $15 \%$, and provided a high statistical power for the most abundant macroinvertebrates. However, the statistical power declined for the less common species, a problem in many marine environmental studies (Dayton et al. 1995, Jennings \& Kaiser 1998).

Many studies examining the effects of scallop harvesting on the marine habitat have been conducted in Europe and Australia, where toothed dredges are used to collect the slightly buried scallops (Chapman et al. 1977, Kaiser et al. 1996, Jennings \& Kaiser 1998, Hill et al. 1999, Hall-Spencer \& Moore 2000, Veale et al. 2000, 2001, Jenkins et al. 2001, Bradshaw et al. 2002). The New Bedford offshore sea scallop dredge rides on 2 shoes and skims over the sea floor, flipping the sea scallops with the sweep chains into the chained bag, and may have less impact on the sea floor than a toothed dredge (Bourne 1964, Caddy 1989).

Previous studies have relied primarily on fishermen's log books to determine fishing effort and, in most cases, this was difficult to quantify (Collie et al. 1997, Collie \& Escanero 2000, Veale et al. 2000). The requirement that scallop fishing vessels in the United States possess a 'Vessel Monitoring System' which transmits the vessel's geographic position every $30 \mathrm{~min}$ has provided highly accurate fishing effort data (Rago et al. 2000). These data allowed us to verify, with a level of confidence previously unattainable, that our control areas were undisturbed and that we had captured the impact of the fishery in our impact areas.

The epibenthic community of the closed areas of Georges Bank did not appear to be detrimentally effected by the limited sea scallop fishery in 2000. Shifts in taxonomic categories and individuals within categories within the areas where the fishery was executed were similar to those in the unfished control areas. Further, the sea floor sediment composition shifted more than the epibenthic community it supported. Therefore, our study suggests that a limited short-term sea scallop fishery alters the epibenthic community less than the natural dynamic environmental conditions of Georges Bank.

Acknowledgements. We thank B. J. Rothschild for his support and guidance. We thank the owners, captains, and crews who sailed with us on the FVs 'Alpha and Omega II', 'Edgartown', 'Friendship', 'Frontier', 'Huntress', 'Liberty', 'Mary Anne' and 'Tradition'. P. Christopher (NMFS) and L. Gavlin (USCG) provided the letters of authorization and insured smooth transitions between fishing and surveying for the vessels. P. Rago (NEFSC, NMFS) kindly allowed the use of the VMS data. M. Stokesbury, M. C. Marino II, J. I. Nogueira and 5 anonymous reviewers provided many helpful comments on the manuscript. Aid was provided by SMAST, the Massachusetts Division of Marine Fisheries, the National Marine Fisheries
Service's sea scallop research set-aside program (NOAA awards: NA16FM1031， NA06FM1001， NA16FM2416, and NA04NMF4720332) and the sea scallop fishery and supporting industries. The views expressed herein are those of the authors and do not necessarily reflect the views of NOAA or any other agencies.

\section{LITERATURE CITED}

Auster PJ, Langton RW (1999) The effects of fishing on fish habitat. In: Benaka L (ed) Fish habitat: essential fish habitat and rehabilitation. American Fisheries Society, Bethesda, MD, p 150-187

Auster PJ, Malatesta RJ, Langton RW, Watling L and 5 others (1996) The impacts of mobile fishing gear on seafloor habitats in the Gulf of Maine (Northwest Atlantic): implications for conservation of fish populations. Rev Fish Sci 4:185-202

Baird FTJ (1954) Migration of deep sea scallop (Pecten magellanicus). Bull Dep Sea Shore Fish Circ 14:1-8

Black R, Miller RJ (1991) Use of the intertidal zone by fish in Nova Scotia. Environ Biol Fish 31:109-121

Black R, Miller RJ (1994) The effects of seaweed harvesting on fishes: a response. Environ Biol Fish 39:325-328

Bourne N (1964) Scallops and the offshore fishery of the Maritimes. Fish Res Board Can 145:1-60

Brown WS, Moody JA (1987) Tides. In: Backus RH (ed) Georges Bank. MIT Press, Cambridge, MA, p 100-107

Bradshaw C, Veale LO, Brand AR (2002) The role of scallopdredge disturbance in long-term changes in Irish Sea benthic communities: a re-analysis of an historical dataset. J Sea Res 47:161-184

Butman B (1987a) The effect of winter storms on the bottom. In: Backus RH (ed) Georges Bank. MIT Press, Cambridge, MA, p 74-76

Butman B (1987b) Physical processes causing surficial sediment movement. In: Backus RH (ed) Georges Bank. MIT Press, Cambridge, MA, p 147-162

Butman B, Beardsley RC (1987) Long-term observations on the southern flank of Georges Bank. Part I. A description of the seasonal cycle of currents, temperature, stratification, and wind stress. J Phys Oceanogr 17:367-384

Caddy JF (1968) Underwater observations on scallop (Placopecten magellanicus) behaviour and drag efficiency. J Fish Res Board Can 25:2123-2141

Caddy JF (1971) Efficiency and selectivity of the Canadian offshore scallop dredge. ICES CM K: 25

Caddy JF (1973) Underwater observations on tracks of dredges and trawls and some effects of dredging on a scallop ground. J Fish Res Board Can 30:173-180

Caddy JF (1989) A perspective on the population dynamics and assessment of scallop fisheries, with special reference to sea scallop, Placopecten magellanicus (Gmelin). In: Caddy JF (ed) Marine invertebrate fisheries: their assessment and management. John Wiley \& Sons, New York, p 559-589

Chapman CJ, Mason J, Kinnear JAM (1977) Diving observations on the efficiency of dredges used in the Scottish fishery for the scallop Pecten maximus (L.). Department of Agriculture \& Fisheries, Aberdeen

Cheng JY, Demont ME (1996) Jet-propelled swimming in scallops: swimming mechanics and ontogenic scaling. Can J Zool 74:1734-1748

Cochran WG (1977) Sampling techniques. John Wiley \& Sons, New York

Collie JS, Escanero GA (2000) Photographic evaluation of the impacts of bottom fishing on benthic epifauna. ICES J Mar Sci 57:987-1001 
Collie JS, Escanero GA, Valentine PC (1997) Effects of bottom fishing on the benthic megafauna of Georges Bank. Mar Ecol Prog Ser 155:159-172

Currie DR, Parry GD (1996) Effects of scallop dredging on a soft sediment community: a large-scale experimental study. Mar Ecol Prog Ser 134:131-150

Currie DR, Parry GD (1999) Impacts and efficiency of scallop dredging on different soft substrates. Can J Fish Aquat Sci 56:539-550

Dadswell MJ, Weihs D (1990) Size-related hydrodynamic characteristics of giant scallop, Placopecten magellanicus (Bivalvia: Pectinidae). Can J Zool 68:778-785

Dayton PK, Thrush SF, Agardy MT, Hofman RJ (1995) Environmental effects of marine fishing. Aquat Conserv: Mar Freshw Ecosyst 5:205-232

Grant J (2000) Modelling approaches to dredging impacts and their role in scallop population dynamics. In: Stokesbury KDE, Feder HM, Paul AJ, Pengilly D, Kruse GH (eds) A workshop examining potential fishing effects on population dynamics and benthic community structure of scallops with emphasis on the weathervane scallop Patinopecten caurinus in Alaskan waters. Spec Publ 14. Alaska Department of Fish and Game, Juneau, AK, p 27-36

Green RH (1979) Sampling design and statistical methods for environmental biologists. John Wiley \& Sons, New York

Hall SJ (1994) Physcial disturbance and marine benthic communities: life in unconsolidated sediments. Oceanogr Mar Biol Annu Rev 32:179-239

Hall-Spencer JM, Moore PG (2000) Impact of scallop dredging on maerl grounds. In: MJ Kaiser, SJ DeGroot (eds) Effects of fishing on non-target species and habitats: biological, conservation and socio-economic issues. Blackwell Science, Oxford, p 105-118

Hill AS, Veale LO, Pennington D, Whyte SG, Brand AR, Hartnoll RG (1999) Changes in Irish Sea benthos: possible effects of 40 years of dredging. Estuar Coast Shelf Sci 48:739-750

Jenkins SR, Beukers-Stewart BD, Brand AR (2001) Impact of scallop dredging on benthic megafauna: a comparison of damage levels in capture and non-captured organisms. Mar Ecol Prog Ser 215:297-301

Jennings S, Kaiser MJ (1998) The effects of fishing on marine ecosystems. Adv Mar Biol 34:201-352

Kaiser MJ, Hill AS, Ramsay K, Spencer BE and 7 others (1996) Benthic disturbance by fishing gear in the Irish Sea: a comparison of beam trawling and scallop dredging. Aquatic Conserv: Mar Freshw Ecosyst 6:269-285

Kenchington E (2000) The seabed impacts of scalloping: the scientific evidence. In: Stokesbury KDE, Feder HM, Paul AJ, Pengilly D, Kruse GH (eds) A workshop examining potential fishing effects on population dynamics and benthic community structure of scallops with emphasis on the weathervane scallop Patinopecten caurinus in Alaskan waters. Spec Publ 14. Alaska Department of Fish and Game, Juneau, AK, p $44-52$

Krebs CJ (1989) Ecological methodology. Harper \& Row, New York

Langton RW, Robinson WE (1990) Faunal associations on scallop grounds in the western Gulf of Maine. J Exp Mar Biol Ecol 144:157-171

Langton RW, Robinson WE, Schick D (1987) Fecundity and reproductive effort of sea scallops Placopecten magellanicus from the Gulf of Maine. Mar Ecol Prog Ser 37:19-25

Lincoln RJ, Boxshall GA, Clark PF (1992) A dictionary of ecology, evolution and systematics. Cambridge University Press, Cambridge

Lindholm J, Auster P, Valentine P (2004) Role of large marine protected area for conserving landscape attributes of sand habitats on Georges Bank (NW Atlantic). Mar Ecol Prog Ser 269:61-68

MacDonald BA (2000) Potential impacts of increased particle concentrations on scallop feeding and energetics. In: Stokesbury KDE, Feder HM, Paul AJ, Pengilly D, Kruse GH (eds) A workshop examining potential fishing effects on population dynamics and benthic community structure of scallops with emphasis on the weathervane scallop Patinopecten caurinus in Alaskan waters. Spec Publ 14. Alaska Department of Fish and Game, Juneau, AK, p 20-26

Mayer LM, Schick DF, Findlay RH, Rice DL (1991) Effects of commercial dragging on sedimentary organic matter. Mar Environ Res 31:249-261

Murawski SA, Brown R, Lai HL, Rago PJ, Hendrickson L (2000) Large-scale closed areas as a fishery-management tool in temperate marine ecosystems: the Georges Bank experience. Bull Mar Sci 66:775-798

Putman RJ (1994) Community ecology. Chapman \& Hall, London

Rago P, Murawski S, Stokesbury K, DuPaul W, McSherry M (2000) Integrated management of the sea scallop fishery in the northeast USA: research and commercial vessel surveys, observers, and vessel monitoring systems. ICES CM 2000/W:13

Rangeley RW (1994) The effects of seaweed harvesting on fishes: a critique. Environ Biol Fish 39:319-323

Stewart-Oaten A, Murdoch WW, Parker KR (1986) Environmental impact assessment: 'pseudoreplication' in time? Ecology 67:929-940

Stokesbury KDE (2002) Estimation of sea scallop abundance in closed areas of Georges Bank, USA. Trans Am Fish Soc 131: 1081-1092

Stokesbury KDE, Himmelman JH (1996) Experimental examination of movement of the giant scallop Placopecten magellanicus. Mar Biol 124:651-660

Stokesbury KDE, Harris BP, Marino II MC, Nogueira JI (2004) Estimation of sea scallop abundance using a video survey in off-shore USA waters. J Shell Fish Res 23:33-44

Thouzeau G, Robert G, Ugarte R (1991) Faunal assemblages of benthic megainvertebrates inhabiting sea scallop grounds from eastern Georges Bank, in relation to environmental factors. Mar Ecol Prog Ser 74:61-82

Tremblay MJ, Loder JW, Werner FE, Naimie CE, Page FH, Sinclair MM (1994) Drift of sea scallop larvae Placopecten magellanicus on Georges Bank: a model study of roles of mean advection, larval behavior and larval origin. Deep-Sea Res 41:7-79

Thrush SF, Hewitt JE, Cummings VJ, Dayton PK (1995) The impact of habitat disturbance by scallop dredging on marine benthic communities: What can be predicted from the results of experiments? Mar Ecol Prog Ser 129:141-150

Underwood AJ (1994) On beyond BACI: sampling designs that might reliably detect environmental distrurbances. Ecol Appl 4:3-15

Veale LO, Hill AS, Hawkins SJ, Brand AR (2000) Effects of longterm physical disturbance by commercial scallop fishing on subtidal epifaunal assemblages and habitats. Mar Biol 137: 325-337

Veale LO, Hill AS, Hawkins SJ, Brand AR (2001) Distribution and damage to the by-catch assemblages of the northern Irish Sea scallop dredge fisheries. J Mar Biol Assoc UK 81: 85-96

Watling L, Norse EA (1998) Physical disturbance of the sea bottom by mobile fishing gear: a comparison with forest clearcutting. Conserv Biol 26:1180-1197

Zar JH (1996) Biostatistical analysis, 3rd edn. Prentice Hall, Upper Saddle River, NJ

Submitted: August 2, 2004; Accepted: July 17, 2005

Proofs received from author(s): December 13, 2005 